\title{
PELATIHAN RECORDING TERNAK RUMINASIA di KELOMPOK TANI BUMDES DESA SALO TIMUR KECAMATAN SALO KABUPATEN KAMPAR
}

\author{
H.Hidayat ${ }^{1}$, U.Habiyah ${ }^{2}$, R.Mulyadi ${ }^{3}$, J.Ashiddiqi ${ }^{4}$ \\ ${ }^{1)}$ Program Studi Peternakan, Fakultas Teknik, Universitas Pahlawan Tuanku Tambusai \\ ${ }^{2,3,4)}$ Mahasiswa Program Studi Peternakan, Fakultas Teknik, Universitas Pahlawan Tuanku Tambusai \\ e-mail: rahmathidayat03121984@gmail.com
}

\begin{abstract}
Abstrak
Populasi ternak kerbau di Kabupaten Kampar menunjukan tren penurunan tiap tahunya, ternak kerbau di Kabupaten Kampar sebanyak 18.134 ekor masih dibawah populasi ternak sapi (40.609 ekor) dan Kambing (25.078 ekor). Hal ini disebabkan oleh pemotongan yang terusmenerus tanpa adanya upaya untuk meningkatkan populasi ternak kerbau dan rendahnya menajemen usaha peternakan salah satunya recording. Untuk itu dibutuhkan pelatihan menajemen peternakan salah salah satunya recording. Metode ini mengakses semua potensi kemampuan peternak kerbau di Kabupaten Kampar khususnya Desa Salo Timur. Proses pembelajaran akan dilaksanakan secara dekokratis melalui metode pendidikan orang dewasa, dimana tim pengabdi hanya sebagai fasilitator dalam penyelesaian masalah. Sedangkan pendampingan difokuskan mulai dari ceramah, tanya jawab dan diskusi. Metode ceramah digunakan untuk memamparkan materi yang telah disusun oleh Tim Pelaksana. Hasil dari pelatihan dan sosialisasi ini adalah masyarakat dan BUMDES Desa Salo Timur mengetahui bagai mana cara beternak dengan menajemen yang baik dan benar untuk mendapatkan hasil yang maksimal dan untuk kerberlangsungan usahanya. Kesimpulan adalah secara umum peternak di Desa Salo Timur sudah mampu menjalankan pemeliharaan ternak dengan baik hanya perlu beberapa peningkatan menajemen sehingga didapatkan hasil yang lebih baik.
\end{abstract}

Kata kunci: Pelatihan, Sosialisasi, Menajemen, Recording

\begin{abstract}
The buffalo population in Kampar Regency shows a decreasing trend every year, 18,134 buffaloes in Kampar Regency are still below the cattle population (40,609 heads) and Goats (25,078 heads). This is caused by continuous slaughter without any effort to increase the buffalo population and the low management of livestock business, one of which is recording. For this reason, livestock management training is needed, one of which is recording. This method accesses all potential capabilities of buffalo farmers in Kampar Regency, especially in East Salo Village. The learning process will be carried out democratically through the adult education method, where the service team only acts as a facilitator in problem solving. Meanwhile, mentoring focused on lectures, questions and answers and discussions. The lecture method is used to present the material that has been prepared by the Implementing Team. The result of this training and socialization is that the community and the BUMDES of East Salo Village know how to raise livestock with good and correct management to get maximum results and for the sustainability of their business. The conclusion is that in general, farmers in East Salo Village have been able to carry out livestock maintenance well, only need some management improvements so that better results are obtained.
\end{abstract}

Keywords:Training, Socialization, Management, Recording 


\section{PENDAHULUAN}

Populasi ternak kerbau di Kabupaten Kampar menunjukan tren penurunan tiap tahunya, ternak kerbau di Kabupaten Kampar sebanyak 18.134 ekor masih dibawah populasi ternak sapi (40.609 ekor) dan Kambing (25.078 ekor) (BPS, 2020). Hal ini disebabkan oleh pemotongan yang terusmenerus tanpa adanya upaya untuk meningkatkan populasi ternak kerbau dan rendahnya menajemen usaha peternakan salah satunya recording.

Masyarakat Kabupaten Kampar pada umumnya beternak kerbau untuk diambil dagingnya dan akan mendapatkan keuntungan besar ketika Idul Adha, karena sebagian besar masyarakat Kabupaten Kampar lebih menyukai daging kerbau dibandingkan daging sapi. Di beberapa daerah di Kabupaten Kampar, Peternak Kerbau juga memanfaatkan susu kerbau untuk mendapatkan penghasilan tambahan.

BUMDES Desa Salo Timur Kabupaten Kampar menjadikan usaha ternak kerbau sebagai usaha utama dari pendapatannya. Pemeliharaan ternak kerbau masih dilakaukan secara semi intensif. Dengan latar belakang hal itu, maka perlu dilakukan pengabdian dengan judul "Pelatihan Recording Ternak Ruminasia Di Kelompok Tani BUMDES Desa Salo Timur Kecamatan Salo Kabupaten Kampar"

\section{Permasalahan Mitra/Kelompok Masyarakat}

Pengetahuan masyarakat tentang menajemen usaha peternakan masih sangat rendah salah satunya recording ini sangat penting dalah usaha peternakan untuk menghindari terjadinya perkawinan Inbreading.

\section{Solusi yang Ditawarkan}

Solusi yang ditawarkan untuk pemecahan masalah adalah memberikan pengetahuan dan pelatihan tentang menajemen usaha peternakan dan pentingnya dilakukan recording untuk mengihdari terjadinya Inbreading.

Dalam pengabdian ini metode pendekatan yang digunakan adalah sosialisasi manajemen pemeliharaan dan recording serta skusi dengan peternak. Tujuan metode ini adalah memberikan pengetahuan pada peternak di Kabupaten Kampar khususnya di Desa Salo Timur tentang pentingnya menajemen usaha peternakan dalam menentukan keberhasilah usah tersebut.

Penyuluhan merupakan cara yang paling efektif dalam meningkatkan pengetahuan dari yang menjadi sasaran pengabdian yaitu peternak kerbau di Kabupaten Kampar. Penyuluhan yang diberikan mengenai menajemen pemeliharaan ternak kerbau yang baik dan sesuai dengan standar.

\section{METODE}

Metode ini mengakses semua potensi kemampuan peternak kerbau di Kabupaten Kampar khususnya Desa Salo Timur. Proses pembelajaran akan dilaksanakan secara dekokratis melalui metode pendidikan orang dewasa, dimana tim pengabdi hanya sebagai fasilitator dalam penyelesaian masalah. Sedangkan pendampingan difokuskan mulai dari ceramah, tanya jawab dan diskusi. Metode ceramah digunakan untuk memamparkan materi yang telah disusun oleh Tim Pelaksana. Penyuluhan dilakukan dalam rangka menambah ilmu dan pengetahuan peternak tentang manajemen pemeliharaan kerbau. Penyuluhan merupakan proses pembelajaran bagi peternak.

\section{HASIL DAN PEMBAHASAN}

Berdasarkan hasil pelaksanaan kegiatan yang telah dilakukan, tampak begitu besar animo masyarakat serta BUMDES Desa Salo Timur Kecamatan Salo Kabupaten Kampar terhadap usaha peternakan kerbau. Hal ini tampak pada saat pelaksanaan kegiatan, begitu banyaknya yang turut hadir di acara tersebut yang terdiri dari bapak-bapak, ibu-ibu serta kalangan anak muda. Adapun yang hadir saat itu ternyata tidak semuanya dari kalangan peternak, banyak juga yang bukan peternak yang antusias menanyakan bagaimana cara beternak kerbau yang benar.

Umumnya peternak kerbau di Kabupaten Kampar khususnya Desa Salo Timur menjadikan usaha ternaknya hanya sebagai usaha sampingan untuk menambah penghasilan keluarga. Disamping memelihara ternak kerbau untuk dijual dagingnya.Pada umumnya pemeliharaan ternak yang dilakukan petani/peternak masih seadanya, baik dalam pemberian makanan maupun dalam manajemen pemeliharaan pada umumnya. Salah satu permasalahan yang dihadapi oleh peternak kerbau di Desa Salo Timur pada umumnya adalah pengetahuan peternak yang masih rendah dalam 
manajemen pemeliharaan baik itu dalam pemberian ransum, pengaturan reproduksi ternak maupun penyakit yang timbul. Dalam hal pemberian pakan, masih banyak peternak yang memberikan pakan ternak seadanya, padahal di sekitar wilayah tersebut banyak ditemukan berbagai hijauan/tanaman yang mempunyai nilai gizi tinggi dan dapat dimanfaatkan sebagai makanan ternak. Demikian halnya dengan sisa/limbah hasil pertanian setiap selesai panen seperti jerami padi, jerami jagung, banyak yang belum memanfaatkannya sebagai makanan ternak, melainkan mereka membuangnya atau membakarnya. Padahal limbah hasil pertanian tersebut cukup banyak dan beraneka jenisnya, serta masih mengandung zat-zat makanan yang diperlukan untuk memenuhi kebutuhan ternak. Disaat panen melimpah dan limbah hasil pertanian pun cukup banyak, jerami tersebut dapat diolah dengan teknologi sederhana menjadi silase, yang hasilnya dapat disimpan sampai berbulan-bulan sebagai simpanan yang diperlukan di saat musim kemarau dimana jumlah hijauan/rumput berkurang. Dalam pemberian makanan penguat atau disebut juga dengan konsentrat, masih banyak peternak yang belum melakukannya oleh karena ketidaktahuan manfaat dari konsentrat.

\section{Manajemen Pemeliharaan Ternak Kerbau}

Manajemen pemeliharaan (recording) adalah salah satu usaha untuk menghindari terjadinya Perkawinan Sedarah atau Inbreading, hal ini dilakukan agar pemuliaan ternak terjaga dengan baik, sehingga bibit yang didapatkan menjadi semakin baik.

Peternak kerbau di Desa Salo Timur Kabupaten Kampar dalam beternak masih mengandalkan cara beternak tradisional serta belum menjalan kan SOP menajemen pemeliharaan yang baik dan benar. Manajemen pemeliharaan yang baik salah satunya recording. Recording yaitu kegiatan pencacatan identitas ternak baik itu tetuahnya, tanggal lahirnya, lama bunting dan lainlain. tindakan ini perlu dilakukan untuk menghindari terjadinya perkawinan sedarah (Inbreading).

Selain proses recording, menjamen pemeliharaan perlu diberikan pemahaman kepada peternak bagaimana cara beternak yang baik dan benar, dari segi nutrisinya, ternak harus diberi makan dengan standar dan kebutuhan harian ternak itu tersebut, menajemen kandang, kandang harus lah terjaga kebersihanya nya untuk menghindari tumbuhnya bakteri yang dapat menimbulkan penyakit.

Beberapa peternak kerbau Desa Salo Timur sudah memenuhi beberapa aspek manajemen pemeliharaan ternak yang baik, diantaranya:

1. Peternak membersihkan kandang dan area sekitar kandang setiap hari.

2. Memberikan Vitamin 3-6 bulan 1 kali.

3. Pemberian Obat cacing setiap 3 bulan 1 kali.

4. Memberikan makan dengan pakan yang berkualitas serta pemberian air secara ad libitum.

Secara umum, peternak kerbau di Desa Salo Timur sudah mampu melakukan Ternak kerbau dengan baik, hanya perlu beberapa peningkatan manajemen sehingga diperoleh hasil yang lebih baik.

\section{SIMPULAN}

Beberapa peternak kerbau Desa Salo Timur sudah memenuhi beberapa aspek manajemen pemeliharaan ternak kerbau yang baik, diantaranya:

1) Peternak membersihkan kandang dan area sekitar kandang setiap hari.

2) Memberikan Vitamin 3-6 bulan 1 kali.

3) Pemberian Obat cacing setiap 3 bulan 1 kali.

4) Memberikan makan dengan pakan yang berkualitas serta pemberian air secara ad libitum.

Secara umum, peternak kerbau di Desa Salo Timur sudah mampu menjalankan menajemen pemeliharaan ternak dengan baik, hanya perlu beberapa peningkatan manajemen sehingga diperoleh hasil yang lebih baik.

\section{SARAN}

Saran yang dapat kami sampaikan setelah melakukan kegiatan Pengabdian kepada Masyarakat di Desa Salo Timur adalah sebagi berikut:

1) Untuk meningkatkan populasi tenak kerbau, peternak harus menjalankan menajemen pemeliharaan ternak untuk mendapatkan hasil yang lebih maksimal. 
2) Perlu dibentuk satu kelompok tani-ternak yang dibina oleh tenaga ahli untuk meningkatkan pengetahuan peternak kerbau di Desa Salo Timur.

\section{UCAPAN TERIMA KASIH}

Penulis mengucapkan terima kasih kepada instansi yang telah memberi dukungan finansian dari LPPM Universitas Pahlawan Tuanku Tambusa terhadap pengabdian ini. dan terimakasih penulis ucapkan kepada masyarakat dan BUMDES Desa Salo Timur yang sudah meluangkan waktunya untuk terlaksananya kegiatan pengabdian kepada masyarakat ini.

\section{DAFTAR PUSTAKA}

Badan Pusat Statistik Kabupaten Kampar. 2020. Kabupaten Kampar dalam angka 2020. Kabupaten Kampar.

Gunawan, E. Romjali, C. Thalib. 2011. Kebijakan Pengembangan Pembibitan Kerbau Mendukung Swasembada Daging Sapi/Kerbau. Di dalam: Percepatan Perbibitan dan Pengembangan Kerbau melalui Kearifan Lokal dan Inovasi Teknologi untuk Mensukseskan Swasembada Daging Kerbau dan Sapi serta Peningkatan Kesejahteraan Peternak. Prosiding Seminar dan Lokakarya Nasional Kerbau; Lebak, 2-4 Nov 2010. Bogor: Pusat Penelitian dan Pengembangan Peternakan. hlm 241-245.

Mirdhayanti, I. J. Handoko dan K. U. Putra. 2008. Mutu susu segar di UPT ruminansia besar. Dinas Peternakan Kabupaten Kampar Provinsi Riau. Fakultas Pertanian dan Peternakan Universitas Islam Negeri Sultan Syarif Kasim. Riau. Jurnal Peternakan Vol 5 No 1: 14-21.

Maulidin, A.M. 2009. Motivasi Peternak dalam Kegiatan Berusaha Ternak Domba di Desa Rancamanyar Kecamatan Baleendah Kabupaten Bandung. Fakultas Peternakan. Universitas Padjadjaran. Bandung.

Maureen, C. E., E. Kardiyanto. 2011. Potensi Pengembangan Kerbau di Provinsi Banten mendukung Swasembada Daging. Di dalam: Percepatan Perbibitan dan Pengembangan Kerbau melalui Kearifan Lokal dan Inovasi Teknologi untuk Mensukseskan Swasembada Daging Kerbau dan Sapi serta Peningkatan Kesejahteraan Peternak. Prosiding Seminar dan Lokakarya Nasional Kerbau; Lebak, 2-4 Nov 2010. Bogor: Pusat Penelitian dan Pengembangan Peternakan. hlm 121-125.

Talib, C. 2008. Kerbau Ternak Potensial yang dianaktirikan. Pusat Penelitian dan Pengembangan Peternakan. Bogor. 